\title{
Exploring Career Management Competencies in Work Based Learning (WBL) Implementation
}

\author{
Azita Ali ${ }^{1}$, Hazlina Marwan ${ }^{2 *}$ \\ ${ }^{1,2}$ Faculty of Technical and Vocational Education, Universiti Tun Hussein Onn Malaysia, Batu Pahat, Johor ,86400, \\ MALAYSIA
}

DOI: https://doi.org/10.30880/jtet.2019.11.01.020

Received 10 September 2018; Accepted 31 October 2018; Available online $31^{\text {st }}$ March 2019

\begin{abstract}
Graduates' employability is a commonly highlighted issue in tertiary education due to today's job market that highly expects the limited vacancies to be filled with competitive and competent graduates. Higher education institutions play a significant role in ensuring and understanding the skills that are needed by the graduates to meet the demand of the professional industry; hence, better job opportunity for the graduates. Work Based Learning (WBL) is one of the platforms for students to gain actual working experience in addition to developing career management competencies to prepare for starting a career. The purpose of this study is to explore the career management competencies that students can master through WBL. This study is a qualitative study that uses analysis of documents and interviews as the primary methods of data collection. Document analysis has been conducted to explore the key elements of competence from the theoretical and literary perspective. Semi-structured interviews were carried out on five selected research experts from various backgrounds and positions in the WBL implementation in polytechnics. Coding and analysis process were conducted based on the recorded transcript of the interview. The collected data were analysed based on the themes that answered the research questions. This study has identified 20 sub-elements covering three key elements of career management competency in the implementation of WBL, namely learning and work exploration, career development, and personal management. The findings of this study are intended to be used as the basis for an effective application of career education in the WBL implementation.
\end{abstract}

Keywords: Career management competencies, Work Based Learning, tertiary education

\section{Introduction}

The current job market is very competitive and in order to compete, graduates need to have high marketability. Employers are selective in recruiting workers to fill vacant positions in the organisation and expect the workforce generated by higher education institutions to be adequately capable in their field of work. As such, higher education institutions play a major role in ensuring and understanding skills that accommodate industry demands, so that graduates have a better career opportunity (McMurray, Dutton, McQuaid, \& Richard, 2016). In addition, graduates' employability is not only measured by outstanding academic achievement but also covers the skills and quality needed by the industry and the job market.

The number of graduates produced by higher education institutions in Malaysia is increasing each year. From 2016 to 2017, the number of graduates graduating increased from 238, 187 to 255,099 graduates (Ministry of Higher Education Malaysia, 2018). This increment will cause competition among graduates in the currently limited employment opportunities. To make matters worse, if the increase in the number of graduates is not accommodated by job opportunities that are suitable to graduates' qualifications and field of study, it will create more serious issues such as unemployment and employability among graduates (Ismail, Ishak Yusof, \& Sieng Lai wei, 2011; Yusof, Jamaluddin, \& Lazim, 2013). 
One of the factors that contribute to the unemployment problem among Malaysian graduates is the poor quality of the graduates (Hanapi \& M. Safarin Nordin, 2014; Ismail et al., 2011). Meanwhile, Sharmila Jayasingam, Yuji Fujiwara, and Ramayah Thurasamy (2016) highlighted that Malaysian graduates today are too choosy when applying for jobs which affected their employability. Based on statistical reports in The National Graduate Employability Blueprint 2012-2017 issued by the Ministry of Higher Education Malaysia (2012), the most common problems identified by employers are poor command of English $(55.8 \%)$, poor character, attitude or personality $(37.4 \%)$, unrealistic salary and benefit (33\%), mismatch of skills $(30.2 \%)$, choosy in job or company $(27.7 \%)$, no demonstrated ability to solve problems $(25.9 \%)$ and having no in depth skill and knowledge $(23.8 \%)$. This finding affirmed that the graduates are weak in the aspect of employability skills and do not show good personalities to remain competitive and get better job opportunities.

Most Malaysian graduates have a low level of career readiness (M. Izwan Mahmud, Sidek M. Noah, Jamaludin Ahmad, \& W. Marzuki W. Ahmad, 2016) and are not actively considering their future career until they graduate (Perrone \& Vickers, 2003). According to the studies by Zaliza Hanapi and Mohd Safarin Nordin (2014), they found that most university students do not have proper planning and strategies for their future career due to the lack of information on the prospect and potential of their careers despite the specificity of their field of study. However, this low level of adequacy is not solely due to lack of students' involvement but also the role of the higher learning institution itself, which does not equip students with the strategies or capabilities needed to comply with the job requirements (Jackson \& Wilton, 2016). Clearly, collaboration and understanding between industries and institutes of higher learning are required to make sure students have the skills and qualifications aligned with the industry needs. Therefore, Bridgstock (2009) recommended that career management competency development has to be initiated in the early stage of the university programme and there should be an assessable course work component.

Career development learning in developing career management competency can be well-oriented through Work Based Learning (WBL) (Jackson \& Wilton, 2016; Watts, 2006). However, the preliminary study results found that there was not enough exposure to the students on specific career management skills that could help them in starting a career. Moreover, there are also several issues in the WBL implementation that are parallel to the argument that the constraints to apply career education in WBL include the difficulties of the stakeholders to understand the diversity of terms and types of workplace learning approaches and the lack of management support at the workplace which made it difficult for the parties of interest to carry it out (Cleary, Horsfall, Muthulakshmi, Happell, \& Hunt, 2013; Jackson \& Wilton, 2016). Based on the discussed research, there is a need to conduct a comprehensive study to enhance the role of WBL in developing the career management competencies required by the students in preparation for entering the real world of work. To achieve this objective, this study explored the elements of career management competency in the WBL implementation that can be mastered by students based on document analysis and expert opinion.

\section{Career Management Competencies}

\subsection{Defining Career Management Competencies}

Career management competencies is defined as the ability to proactively navigate the career world and successfully manage career development based on lifelong learning skills and adaptability (Bridgstock, 2009). Australia's Blueprint for Career Development (MCEECDYA, 2010), developed between 2003 and 2008 defines career management competencies as something more than technical skills and abilities, but also involve skills, knowledge and attitude in order to secure a good career which can be developed and enhanced from time to time.

Based on literature reviews, there are various models of career management competencies that outline some of the major domains. As an example, the DOTS Model developed by Watts (2006) is a model that can be used to organise experience through WBL in the development of career education (Reddan \& Rauchle, 2012). This model consists of four domains, namely self-awareness, decision-making skills, opportunity awareness, and transition learning. Bridgstock (2009) introduced a career management competencies model to improve the employability of graduates which emphasises on the domain of self-management skills and career building skills. Akkermans, Brenninkmeijer, Huibers, and Blonk (2013) developed a three-dimensional career competencies model: reflective, communicative, and behavioural competencies, where each dimension contains two career competencies.

The Australian Blueprint for Career Development Framework (MCEECDYA, 2010) was developed to support career development programmes in Australia. The Blueprint consists of 11 competencies comprising three main domains namely personal management, learning and work exploration, and career building. The domain listing of career management competencies discussed above proves that there is a diverse domain of career management competency and it is moulded based on the needs and focus of the research conducted. In short, the domain of career management competencies is based on three key elements of self-management, career, and learning process (Hooley, Watts, \& Sultana, 2013).

Career management competencies are crucial for long term career development (Jackson \& Wilton, 2016). From an individual point of view, career management can help to develop an understanding of career choices (Miller \& Liciardi, 2003) and promote reflection on career options and pathways (Greenbank, 2011). In order to obtain and 
maintain employment in a constantly changing labour market, one needs career competencies that can help them manage their career well (Jos Akkermans et al., 2012; Heijde \& Heijden, 2006). In summary, career management competencies can help individuals make career choices and foster personal development as well as highlight the potential of individuals in their profession. Therefore, in order to produce competent students, career education that provides technical information, skills and career awareness is essential (Ayranci \& Ercan, 2011). Higher education institutions should play a vital role in providing education and awareness on career management in order to have a positive impact on students' development and progress.

\subsection{Role of Work Based Learning in Development of Career Management Competencies}

The term Work Based Learning (WBL) encompasses a variety of purposes, but clearly the main location of learning is the workplace and basically, the basic concept of WBL aims to add layers of experience in existing conceptual knowledge. According to the Malaysian Qualifications Agency (2016), WBL is a subset of learning at the workplace and in particular it refers to the achievement of organised learning outcomes acquired through experience of performing roles or work functions. Felicity and Linda (2013) explained that WBL is a programme that provides internships, mentoring, workplace simulations and apprenticeship together with lecture learning in which students undergo out-ofclassroom learning that enables students to gain real-time working experience.

Watts (2006) explained that the WBL programme can be well-planned in collaborating academicians and employers in order to motivate students to be more active and positive in the career development process. Learning environments through WBL can stimulate the development and application of career competencies because students have the opportunity to gain real work experience (Kuijpers \& Meijers, 2012). This is also explained by research findings by Jackson and Wilton (2016) which demonstrated that learning at work is a good platform to develop selfawareness competency among students; thus, it also has a positive influence on the development of decision-making skills, opportunity awareness, and transition learning.

Through WBL, students can increase their readiness to work in terms of non-technical skills development such as self-efficacy, team skills and teamwork (Smith \& Worsfold, 2014). In addition, WBL can also contribute to enhancing students' understanding of skills and specific roles in real-world employment (Jackson, 2015). Overall, it can be concluded that various contexts of real-time work experience enriched through the WBL implementation can provide opportunities for students to develop their early career.

\section{Methodology}

This study used a qualitative approach with the aim to carry out a deeper exploration of the elements of career management competencies that students can master in the implementation of Work Based Learning (WBL). This is in line with the study by Smith and Morse (2005) which clarified that qualitative studies are appropriate for measuring something subjective, difficult to evaluate, and has broad concepts such as competency studies. Purposive sampling method was used to determine the selected participants to meet the criteria required in responding to the questions of the study.

\subsection{Participants}

In this study, the researcher selected five experts for face-to-face interviews: expert 1 is referred to as $\mathrm{P} 1$, expert 2 as $\mathrm{P} 2$, expert 3 as P3, expert 4 as $\mathrm{P} 4$ and expert 5 as P5. All the experts are from various backgrounds and positions in the WBL implementation in polytechnics. According to Creswell and Plano Clark (2011), the sample size is dependent on the questions and also the qualitative approach used; for case studies, the number of participants required is usually between 4 to 10 respondents. The rationale for this specialist selection is to gain a wide range of different experience and perspectives on career management competencies based on their respective field of expertise in the WBL implementation, especially in polytechnics. Berliner (2004) explained that those with experience in a field for over five years can be classified as experts. While in education, experts refer to individuals with more than five years of experience and based on their specific experience (Akbari \& Yazdanmehr, 2014).void hyphenation at the end of a line. Symbols denoting vectors and matrices should be indicated in bold type. Scalar variable names should normally be expressed using italics. Weights and measures should be expressed in SI units. All non-standard abbreviations or symbols must be defined when first mentioned, or a glossary provided.

\subsection{Data Collection Procedure}

To explore the elements of Career Management competency in the implementation of WBL, this study used two methods, namely (i) based on the analysis of the documents by making literature review through the integration of models and theories related to career management competencies as well as the implementation of WBL and (ii) interview with the stakeholders in the implementation of WBL in Malaysian polytechnics.

The interviews were semi-structured interviews. This is because individual semi-structured interviews allow the interviewer to personally prompt individuals about their view, opinion or understanding in the subjects of the study 
(DiCicco-Bloom \& Crabtree, 2006). In order to maintain a clear focus in line with the selection of interviewing techniques, careful preparations are necessary to obtain maximum input to answer the research questions (Turner, 2010). Hence, the researcher made early planning in two important aspects of preparation i.e identifying individuals to be interviewed and preparing the interview protocols. Preparation of this interview protocol included developing, organising and validating interview questions. In addition, the researcher also obtained the experts' permission to be interviewed.

The interview process was done within two months. Each interview session took approximately 30 minutes. Some principles were applied and emphasised at this stage such as making appointment, explaining the purpose of the study, showing confidence to interview, explaining the interview format, informing the interview duration and ensuring that the installed recording devices did not interfere with the interview session.

\subsection{Data Analysis}

The analysis of the interview data began once the first interview process took place. Data obtained from audio recording were transcribed in verbatim form and verified by the participants to ease the researcher in making further analysis. This is in line with Merriam's (2009) view that verbatim transcription is the best database for analysis. After conducting the transcription process, the researcher compiled and segregated the data according to the importance of the study so that non-essential data could be isolated. Subsequently, the coding and analysis process were conducted based on the recorded transcript of the interview. Coding is a method that allows researchers to include passages or sentences to groups that have the same meaning or are categorised as "family" because of characteristic similarities (Corbin \& Strauss, 2008). In this stage, researchers use interpretation skills to find frequent, unique, relevant and interesting codes for coding purposes. The final analysis process was thematic and narrative analyses where the researcher reported the findings in the form of storytelling supported by the interview quotes.

\section{Results and Discussion}

This study has met the research objectives of identifying all of the possible competencies perceived by experts of WBL as important with regard to the WBL implementation. The results of the analysis obtained from the literature review and interviews found three key elements of career management competencies in WBL, namely Personal Management, Learning and Work Exploration, and Career Building. In each of these elements, there are several sub-elements of competence from the perspective of the research experts who has been chosen in the WBL implementation in polytechnics. The findings of the interview analysis conducted on five experts related to the study were supported and in parallel with the analysis of the documented data.

\subsection{Elements of Personal Management}

Personal Management is a competence related to individual perceptions and appraisal of themselves in terms of value, ability, interest and goals (Bridgstock, 2009). The study by Eby, Butts, and Lockwood (2003) showed that students with clear career goals, realistic assessment of their capabilities and abilities have better employability than other students

Table 1 - Sub-elements of Personal Management

\begin{tabular}{|c|c|c|c|c|c|c|}
\hline No & Elements & P1 & $\mathbf{P 2}$ & P3 & $\mathbf{P 4}$ & P5 \\
\hline \multicolumn{7}{|c|}{ Personal Management } \\
\hline 1 & Positive self-image & $\sqrt{ }$ & $\sqrt{ }$ & $\sqrt{ }$ & & $\sqrt{ }$ \\
\hline 2 & Effective communication & $\sqrt{ }$ & $\sqrt{ }$ & $\sqrt{ }$ & $\sqrt{ }$ & $\sqrt{ }$ \\
\hline 3 & Improving self confidence & & & $\sqrt{ }$ & $\sqrt{ }$ & $\sqrt{ }$ \\
\hline 4 & Maintaining good relationship & & $\sqrt{ }$ & $\sqrt{ }$ & & $\sqrt{ }$ \\
\hline 5 & Environment adaptation & $\sqrt{ }$ & $\sqrt{ }$ & $\sqrt{ }$ & & $\sqrt{ }$ \\
\hline 6 & Personal and work balance & & $\sqrt{ }$ & & & $\sqrt{ }$ \\
\hline 7 & Creative and innovative & & $\sqrt{ }$ & $\sqrt{ }$ & & $\sqrt{ }$ \\
\hline 8 & Sensitive to change & & & & $\sqrt{ }$ & $\sqrt{ }$ \\
\hline
\end{tabular}

The summary of interview in Table 1 shows eight sub-elements under the personal management competence. Subelements that can be mastered through WBL are positive self-image (4 experts), effective communication (5 experts), improved self-confidence (3 experts), maintaining good relationships (3 experts), adapting to the environment (4 experts), work and personal balance ( 2 experts), creative and innovative (3 experts), and sensitive to change ( 2 experts). Here are some of the interviews excerpts with the research experts with regard to personal management competencies: 
"In my opinion, a lot can be achieved through personal management. For example, positive self-image which shows they can work better compared to other graduates in different industries... "(P2)

"I think there are many improvements in personal management...Before, he was not articulate. But since he was sent to the industry, he was given the same treatment and training as the existing employees; thus, he had the chance to develop his communication skill..." (P4)

"...which means we will polish his leadership skill, social skill and others. And also communication skills. When they are in the workplace, the environment is different from the classroom. They have to mingle with all the other staff and they will get early training and exposure..."(P5)

Based on the findings presented, it was observed that workplace learning through WBL can equip students with good personal management elements. The results of personal management competency are similar to those obtained by other studies (Akkermans, Schaufeli, Brenninkmeijer, and Blonk, 2013; Bridgstock, 2009; Kong and Yan, 2014; Vaughan, 2011; Watts, 2006) that considered positive self-image, effective communication, improved self-confidence, maintaining good relationships, adapting to the environment, work and personal balance, creative and innovative, and sensitive to change as competencies with the highest importance for career development. Clearly, more exposure on workplace learning helps students develop their interpersonal interaction and positive attitude. This is in line with Reddan and Rauchle (2012) who emphasised that the development of personal management competency will enhance a student's long-term employability.

\subsection{Elements of Learning and Work Exploration}

Work exploration is defined as an active act to explore and find relevant opportunities related to work and career (Jos Akkermans et al., 2012), while learning is a process where students can transform information into meaningful knowledge. Therefore, students need to be exposed to learning environments that could enable them to make their own choices, motivate themselves and have the ability to achieve their career goals (Kuijpers \& Meijers, 2012).

Table 2- Sub-elements of Learning and Work Exploration

\begin{tabular}{|c|c|c|c|c|c|c|}
\hline No & Element & $\mathbf{P 1}$ & $\mathbf{P 2}$ & $\mathbf{P 3}$ & $\mathbf{P 4}$ & P5 \\
\hline \multicolumn{7}{|c|}{ Learning and work exploration } \\
\hline 1 & Explore career information & $\sqrt{ }$ & & $\sqrt{ }$ & $\sqrt{ }$ & $\sqrt{ }$ \\
\hline 2 & Use career information effectively & $\sqrt{ }$ & & $\sqrt{ }$ & $\sqrt{ }$ & $\sqrt{ }$ \\
\hline 3 & Relate learning to career goals & & $\sqrt{ }$ & & & $\sqrt{ }$ \\
\hline 4 & Build work networking & $\sqrt{ }$ & $\sqrt{ }$ & & $\sqrt{ }$ & \\
\hline 5 & Mastering knowledge in a specialised field & $\sqrt{ }$ & $\sqrt{ }$ & $\sqrt{ }$ & $\sqrt{ }$ & $\sqrt{ }$ \\
\hline
\end{tabular}

The findings of the interviews as illustrated in Table 4.2 show five sub-elements under the Learning and Work Exploration competencies. All five experts stated that students can master knowledge in specialised field, four experts (P1, P3, P4 and P5) stated that students can master, explore and use career information effectively, three experts (P1, P2 and P4) stated that students can master the elements of network building and two experts (P3 and P5) stated that students can master elements of relating learning to career goals through WBL. Here are some of the interview excerpts with the research experts related to learning and work exploration competencies:

"...for example, from the previous first batch, three students worked in the same industry that was involved in WBL and the others explored the industries that are in their expertise such as ASTRO and a few advertising companies. This is because during WBL in the industry, they have started making portfolios and obtaining recommendations from those companies which allow students to easily secure a job position... "(P4)

“...Some devices were not repairable or still under the warranty thus students need to be in contact with suppliers or vendors. Students got the chance to build connection and network with other companies. Unintentionally, they can use this networking to look for job opportunity after they graduated... "(P2)

Based on the results, it was found that WBL also appeared to positively impact the development of Learning and Work Exploration competencies. This is consistent with the findings of Werbel (2000) in which graduates who are active in the career exploration process will have a good level of job readiness and gain a lot of success. Similarly, McIlveen et al. (2011) found that learning activities that include career education in WBL can help the students' career 
development. Therefore, as students, they must always be sensitive to the changing working world to align their interests and goals in the right direction of work.

\subsection{Elements of Career Building}

Table 3- Sub-elements of Career Building

\begin{tabular}{|c|c|c|c|c|c|c|}
\hline No & Element & P1 & $\mathbf{P 2}$ & P3 & $\mathbf{P 4}$ & P5 \\
\hline \multicolumn{7}{|c|}{ Career Building } \\
\hline 1 & Career planning & & $\sqrt{ }$ & & $\sqrt{ }$ & $\sqrt{ }$ \\
\hline 2 & Improve decision making skills & & & $\sqrt{ }$ & $\sqrt{ }$ & $\sqrt{ }$ \\
\hline 3 & Teamwork ability & $\sqrt{ }$ & & $\sqrt{ }$ & & $\sqrt{ }$ \\
\hline 4 & Master managing skills & $\sqrt{ }$ & & $\sqrt{ }$ & $\sqrt{ }$ & $\sqrt{ }$ \\
\hline 5 & Enhance report writing skills & & $\sqrt{ }$ & & $\sqrt{ }$ & $\sqrt{ }$ \\
\hline 6 & Ability to present & & $\sqrt{ }$ & $\sqrt{ }$ & $\sqrt{ }$ & \\
\hline 7 & Master good English proficiency & & & & $\sqrt{ }$ & $\sqrt{ }$ \\
\hline
\end{tabular}

The thematic analysis carried out in this study also identified seven sub-elements under the career building competencies as set out in Table 4.3. Through WBL, three different research experts have stated that students can master elements such as career planning, decision-making skills, teamwork ability, enhancing report writing skills and being able to present, four experts (P1, P3, P4 and P5) stated that students can master the elements of managing skills and two research experts (P4 and P5) said that students can master good English proficiency. Here are some of the interviews excerpts with research experts related to career building competency:

“...These students had the opportunity to be on the site to meet vendors, suppliers and had been assigned with projects to be managed. This is where students could develop various working skills and competencies." (P1)

"Actually, after WBL, students were able to make better decisions with better self-confidence. For example, in a travel agency, they were not trusted but after training and facilitating, the students were given the authority to make decisions...."(P3)

".... another required skill is the ability to explain. As a technical person, these students will just do their work and not talk to anyone. That is the nature of the job. So, in this industry, we want to train students to be able to explain to the user about the damage and other related issues. Here is where the element of presentation comes in..."(P2)

The results of career building competency are similar to those obtained by previous studies that considered career planning (Akkermans et al., 2013; Bridgstock, 2009; Watts, 2006), decision-making skills (Vaughan, 2011; Watts, 2006) and teamwork ability (Kong \& Yan, 2014) as crucial career abilities. The findings affirmed that real-time experience through WBL can expose students to a variety of generic skills that can help in the development of the students' careers. This is in line with the argument of Kong and Yan (2014) stating that experiential learning can increase interest in the field, increase satisfaction, and further promote generic skills such as analytic reasoning, problem-solving and critical thinking. Additionally, students can enhance their learning experience and better adapt their knowledge through activities in experiential learning.

\section{Conclusions}

This study has shown that the opportunity to gain real work experience through Work Based Learning (WBL) can help students master the career management competencies needed to start and build their future career. The findings of this study have found 20 sub-elements comprising three key elements of career management competencies in the implementation of WBL. These elements of competence are able to mould students into flexible workers as required by the employers. Furthermore, it is hoped that this study can be used to plan career education programmes in WBL more effectively and bring benefits to the students. This is because emphasis on the development of this competency will make the students more ready and competent to work and be marketable in the increasingly competitive work market. 


\section{Acknowledgement}

The funding for this research was provided by the University Tun Hussein Onn Malaysia under the STG grant (Vot U535)

\section{References}

Akbari, R., \& Yazdanmehr, E. (2014). A Critical Analysis of the Selection Criteria of Expert Teachers in ELT. Theory and Practice in Language Studies, 4(8), 1653-1658. doi:10.4304/tpls.4.8.1653-1658

Akkermans, J., Brenninkmeijer, V., Huibers, M., \& Blonk, R. W. B. (2012). Competencies for the Contemporary Career: Development and Preliminary Validation of the Career Competencies Questionnaire. Journal of Career Development, 40(3), 245-267. doi:10.1177/0894845312467501

Akkermans, J., Schaufeli, W. B., Brenninkmeijer, V., \& Blonk, R. W. B. (2013). The role of career competencies in the Job Demands — Resources model. Journal of Vocational Behavior, 83(3), 356-366. doi:10.1016/j.jvb.2013.06.011

Ayranci, E., \& Ercan, O. (2011). A Study of the Relationship Between Students'Views Toward a Career Management Class and Their Future Careers. International Business Research, 4(1), 198-207.

Berliner, D. C. (2004). Describing the Behavior and Documenting the Accomplishments of Expert Teachers. Bulletin of Science, Technology \& Society, 24(3), 200-212. doi:10.1177/0270467604265535

Bridgstock, R. (2009). The graduate attributes we've overlooked: enhancing graduate employability through career management skills. Higher Education Research \& Development, 28(1), 31-44. doi:10.1080/07294360802444347

Cleary, M., Horsfall, J., Muthulakshmi, P., Happell, B., \& Hunt, G. E. (2013). Career development: Graduate nurse views. Journal of Clinical Nursing, 22(17-18), 2605-2613. doi:10.1111/jocn.12080

Corbin, J. M., \& Strauss, A. L. (2008). Basics of qualitative research: Techniques and procedures for developing grounded theory. SAGE Publications, Inc.

Creswell, J. W., \& Plano Clark, V. L. (2011). Designing And Conducting Mixed Methods Research. (V. Knight, Ed.) (2nd ed). SAGE Publication.

DiCicco-Bloom, B., \& Crabtree, B. F. (2006). The qualitative research interview. Medical Education, 40(4), 314-321. doi:10.1111/j.1365-2929.2006.02418.x

Eby, Li. T., Butts, M., \& Lockwood, A. (2003). Predictors of success in the era of the boundaryless career. Journal of Organizational Behavior, 24, 689-708. doi:10.1108/13620430710834396

Greenbank, P. (2011). Improving the process of career decision making: an action research approach. Education + Training, 53(4), 252-266.

Hanapi, Z., \& M. Safarin Nordin. (2014). Unemployment Among Malaysia Graduates:Graduates'attributes,Lecturers' Competency And Quality Of Education. Paper presented at the International Conference on Education \& Educational Psychology 2013 (ICEEPSY 2013) 112, 1056-1063. doi: 10.1016/j.sbspro.2014.01.1269

Heijde, C. M. Van Der, \& Heijden, B. I. J. . Van Der. (2006). A Competence-Based And Multidimensional Operationalization And Measurement of Employability. Human Resource Management, 45(3), 449-476. doi: $10.1002 / \mathrm{hrm} .20119$

Hooley, T., Watts, A. G., \& Sultana, R. G. (2013). British Journal of Guidance \& The ' Blueprint' framework for career management skills: a critical exploration. British Journal of Guidance \& Counselling, 41(2), 117-131. doi:10.1080/03069885.2012.713908

Ismail, R., Ishak Yusof, \& Sieng Lai wei. (2011). Employers' perceptions on graduates in Malaysian services sector. International Business Management, 5(3), 184-193. doi:doi.org/10.3923/ibm.2011

Jackson, D. (2015). Employability skill development in work-integrated learning: Barriers and best practice. Studies in Higher Education, 40(2), 350-367.

Jackson, D., \& Wilton, N. (2016). Developing career management competencies among undergraduates and the role of work-integrated learning. Teaching in Higher Education, 21(3), 266-286. doi:10.1080/13562517.2015.1136281

Kong, H., \& Yan, Q. (2014). The relationship between learning satisfaction and career competencies. International Journal of Hospitality Management, 41, 133-139. doi:10.1016/j.ijhm.2014.05.013 
Kuijpers, M., \& Meijers, F. (2012). Learning for now or later? Career competencies among students in higher vocational education in the Netherlands. Studies in Higher Education, 37(4), 449-467. doi:10.1080/03075079.2010.523144

M. Felicity, R.-C., \& Linda, D.-H. (2013). Preparing 21st Century Citizens: The Role of Work-Based Learning in Linked Learning. Education. Stanford, CA.

M. Izwan Mahmud, Sidek M. Noah, Jamaludin Ahmad, \& W. Marzuki W. Ahmad. (2016). Modul Kesediaan Kerjaya Berdasarkan Teori Cognitive Information Processing (CIP). Jurnal Kurikulum \& Pengajaran Asia Pasifik, 4(3), 59-75.

Malaysian Qualifications Agency. (2016). Garis Panduan Amalan Baik : Pembelajaran Berasaskan Kerja. Petaling Jaya Selangor: Malaysian Qualifications Agency. Retrieved from http//www.mqa.gov.my on June 2017

MCEECDYA. (2010). Australian Blueprint For Career Development. Miles Morgan Australia. Canberra Austrlia: Commonwealth of Australia. Retrieved from www.blueprint.edu.au on September 2017

McIlveen, P., Brooks, S., Lichtenberg, A., Smith, M., Torjul, P., \& Tyler, J. (2011). Career Development Learning Frameworks for Work-Integrated Learning. Developing Learning Professionals: Integrating Experiences in University and Practice Settings, 7, 149-165. doi:10.1007/978-90-481-3937-8_9

McMurray, S., Dutton, M., McQuaid, R., \& Richard, A. (2016). Employer demands from business graduates. Education + Training, 58(1), 112-132 doi:10.1108/ET-02-2014-0017

Merriam, S. B. (2009). Qualitative research: A guide to design and implementation (2 ${ }^{\text {nd }}$ ed). San Francisco, CA: Jossey-Bass

Miller, S., \& Liciardi, R. (2003). Tertiary student perceptions of the benefits of professional career management education : an exploratory study. Career Development International, 8(6), 309-315. doi:10.1108/13620430310496125

Ministry of Higher Education Malaysia. (2012). The National Graduate Employability Blueprint (2012-2017). Putrajaya, MALAYSIA.

Ministry of Higher Education Malaysia. (2018). Statistik Pendidikan Tinggi 2017. Kuala Lumpur, Malaysia.

Perrone, L., \& Vickers, M. H. (2003). Life after graduation as a \&quot;very uncomfortable world\&quot;: An Australian case study. Education \& Training, 45(2), 69-78.

Reddan, G., \& Rauchle, M. (2012). Student Perceptions of the Value of Career Development Learning to a WorkIntegrated Learning Course in Exercise Science. Australian Journal of Career Development, $21(1), 38-48$. doi: $10.1177 / 103841621202100106$

Sharmila Jayasingam, Yuji Fujiwara, \& Ramayah Thurasamy. (2016). Studies in Higher Education 'I am competent so I can be choosy ': choosiness and its implication on graduate employability. Studies in Higher Education, 0(0), 1-16. doi: $10.1080 / 03075079.2016 .1221918$

Smith, B., \& Morse, E. (2005). Entrepreneurial competencies: Literature review and best practises. Small Business Policy Branch Industry Canada.

Smith, C., \& Worsfold, K. (2014). WIL curriculum design and student learning : a structural model of their effects on student satisfaction. Studies in Higher Education, 39(6), 1070-1084. doi:10.1080/03075079.2013.777407

Turner, D. W. (2010). Qualitative interview design: A practical guide for novice investigators. The Qualitative Report (Vol. 15).

Vaughan, K. (2011). The potential of career management competencies for renewed focus and direction in career education. New Zealand Annual Review of Education, 20, 24-51.

Watts, A. G. (2006). Career development learning and employability. The Higher Education Academy. United Kingdom.

Werbel, J. D. (2000). Relationships among Career Exploration, Job Search Intensity, and Job Search Effectiveness in Graduating College Students. Journal of Vocational Behavior, 57(3), 379-394. doi:10.1006/jvbe.2000.1746

Yusof, N., Jamaluddin, Z., \& Lazim, N. M. (2013). Persepsi Pelajar Prasiswazah Terhadap Kebolehpasaran Graduan dan Persaingan dalam Pasaran Pekerjaan. Jurnal Personalia Pelajar, 16, 77-92. 